\title{
SITUASI PNEUMONIA DI WILAYAH KERJA DINAS KESEHATAN KABUPATEN GOWA SULAWESI SELATAN TAHUN 2017
}

\author{
Wibowo ${ }^{1}$,Rudi Hendro Putranto ${ }^{1}$, Widianto $^{1}$, Sahir $^{2}$
}

1. Pusat Penelitian Dan Pengembangan Sumber Daya Dan Pelayanan Kesehatan

Badan Penelitian Dan Pengembangan Kesehatan,Kementerian Kesehatan RI,Jakarta.

2. Dinas Kesehatan Kabupaten Gowa Propinsi Sulawesi Selatan

Email : wibowo869@yahoo.co.id

\begin{abstract}
Pneumonia infection arises because of the invasion of microorganisms or viruses, bacteria or fungi in the lungs. Generally pneumonia is characterized by phlegm coughing with greenish or yellow sputum, high fever and shivering and shortness of breath. The purpose of this study was to obtain a description of pneumonia cases in the work area of the Gowa District Health Office. The results of the study found that the highest finding of pneumonia cases in children under five in Gowa Regency was $57.7 \%$ in boys. Whereas $42.3 \%$ was found in female toddlers. Based on the results of the study, it can be seen that the highest finding of pneumonia cases in infants in the Gowa Regency area is $27.5 \%$ in Sombaopu District. The lowest case finding for infants in the Gowa Regency area is $0.1 \%$ in South Bontonompo District. It was found that the highest finding of pneumonia cases in infants in the Gowa Regency area was $28.3 \%$ found in the Sombaopu Health Center. Whereas the lowest case finding for toddlers in the Gowa Regency area is $0.1 \%$ in Bontonompo I Health Center. Conclusions are still found in pneumonia cases with the number of cases below the national figure of $2 \%$.
\end{abstract}

Keywords: pneumonia cases and the work area of the Gowa District Health Office

Abstrak

Infeksi Pneumonia muncul karena adanya invasi mikroorganisme atau virus, bakteri atau jamur pada paru-paru.Umumnya pneumonia ditandai dengan batuk-batuk berdahak dengan sputum kehijauan atau kuning, demam tinggi dan menggigil serta nafas yang pendek. Tujuan penelitian ini adalah diperolehnya gambaran kasus pneumonia di wilayah kerja Dinas Kesehatan Kabupaten Gowa. Hasil penelitian ditemukan bahwa penemuan kasus pneumonia tertinggi pada balita di wilayah Kabupaten Gowa adalah sebesar $57,7 \%$ terjadi pada balita laki-laki. Sedangkan sebesar $42,3 \%$ ditemukan pada balita perempuan. Berdasarkan hasil penelitian dapat diketahui bahwa penemuan kasus pneumonia tertinggi pada balita di wilayah Kabupaten Gowa adalah sebesar 27,5\% yang terdapat di Kecamatan Sombaopu. Untuk penemuan kasus terendah pada balita di wilayah Kabupaten Gowa adalah sebesar $0,1 \%$ yang terdapat di Kecamatan Bontonompo Selatan. Ditemukan bahwa penemuan kasus pneumonia tertinggi pada balita di wilayah Kabupaten Gowa adalah sebesar 28,3\% yang terdapat di Puskesmas Sombaopu. Sedangkan penemuan kasus terendah pada balita di wilayah Kabupaten Gowa adalah sebesar 0,1\% yang terdapat di Puskesmas Bontonompo I Kesimpulan masih ditemukan kasus pneumonia dengan jumlah kasus dibawah angka nasional yaitu $2 \%$.

Kata kunci : kasus pneumonia dan wilayah kerja Dinkes Kabupaten Gowa

\section{PENDAHULUAN.}

Pada umumnya, pneumonia dikategorikan dalam penyakit menular yang ditularkan melalui udara, dengan sumber penularan adalah penderita pneumonia yang menyebarkan kuman dalam bentuk droplet ke udara pada saat batuk atau bersin. Untuk selanjutnya, kuman penyebab pneumonia masuk ke saluran pernapasan melalui proses inhalasi (udara yang dihirup), atau dengan cara penularan langsung, yaitu percikan droplet yang dikeluarkan oleh penderita saat batuk, bersin, dan berbicara langsung terhirup oleh orang di sekitar penderita, atau memegang dan menggunakan benda yang telah terkena sekresi saluran pernapasan penderita.
Sampai saat ini, penyakit pneumonia merupakan penyebab utama kematian balita di dunia. Diperkirakan ada 1,8 juta atau $20 \%$ dari kematian anak diakibatkan oleh pneumonia, melebihi kematian akibat AIDS, malaria dan tuberkulosis. ${ }^{1}$ Adanya Pneumonia ditandai dengan batuk dan kesulitan bernapas yaitu napas cepat, dan tarikan dinding dada bagian bawah ke dalam. ${ }^{2}$

$\mathrm{Di}$ Indonesia, pneumonia juga merupakan urutan kedua penyebab kematian pada balita setelah diare. Riset Kesehatan Dasar (Riskesdas) melaporkan bahwa kejadian pneumonia sebulan terakhir (period prevalence) mengalami peningkatan pada tahun 2007 
sebesar 2,1\%o menjadi 2,7 \%o pada tahun 2013. Kematian balita yang disebabkan oleh pneumonia tahun 2007 cukup tinggi, yaitu sebesar $15,5 \%$. 2,3 Demikian juga hasil Survei Demografi dan Kesehatan Indonesia (SDKI), yang melaporkan bahwa prevalensi pneumonia dari tahun ke tahun terus meningkat, yaitu 7,6\% pada tahun 2002 menjadi $11,2 \%$ pada tahun 2007.4,5

Pneumonia merupakan penyakit dari paru-paru dan sistem pernapasan dimana alveoli (mikroskopik udara mengisi kantong dari paru yang bertanggung jawab untuk menyerap oksigen dari atmosfer) menjadi radang dan dengan penimbunan cairan. Pneumonia disebabkan oleh berbagai macam sebab,meliputi infeksi karena bakteri,virus,jamur atau parasit. Pneumonia juga dapat terjadi karena bahan kimia atau kerusakan fisik dari paru- paru,atau secara tak langsung dari penyakit lain seperti kanker paru atau penggunaan alkohol. Gejala khas yang berhubungan dengan pneumonia meliputi batuk,nyeri dada demam,dan sesak nafas.Alat diagnosa meliputi sinar- $x$ dan pemeriksaan sputum.Pengobatan tergantung penyebab dari pneumonia; pneumonia kerena bakteri diobati dengan antibiotika. Pneumonia merupakan penyakit yang umumnya terjadi pada semua kelompok umur, dan menunjukan penyebab kematian pada orang tua dan orang dengan penyakit kronik. Tersedia vaksin tertentu untuk pencegahan terhadap jenis pnuemonia. Prognosis untuk tiap orang berbeda tergantung dari jenis pneumonia, pengobatan yang tepat,ada tidaknya komplikasi dan kesehatan orang tersebut Kementerian Kesehatan Republik Indonesia. ${ }^{7}$

Sampai dengan tahun 2013, angka cakupan penemuan pneumonia balita tidak mengalami perkembangan berarti yaitu berkisar antara 23\%-27\%. Selama beberapa tahun terakhir cakupan penemuan pneumonia tidak pernah mencapai target nasional, termasuk target tahun 2013 yang sebesar 80\%. Angka kematian akibat pneumonia pada balita sebesar $1,19 \%$. Pada kelompok bayi angka kematian lebih tinggi yaitu sebesar 2,89\% dibandingkan pada kelompok umur 1-4 tahun yang sebesar $0,20 \% .^{8}$

Pneumonia adalah penyakit yang disebabkan kuman pneumococcus, staphylococcus, streptococcus, dan virus. Gejala penyakit pneumonia yaitu menggigil, demam, sakit kepala, batuk, mengeluarkan dahak, dan sesak napas. Populasi yang rentan terserang pneumonia adalah anak-anak usia kurang dari 2 tahun, usia lanjut lebih dari 65 tahun dan orang yang memiliki masalah kesehatan (malnutrisi, gangguan imunologi). Menurut hasil Riskesdas 2013, period prevalence pneumonia berdasarkan diagnosis selama 1 bulan sebelum wawancara sebesar $0,2 \%$. Sedangkan berdasarkan diagnosis/gejala sebesar $1,8 \%$. Dibandingkan dengan hasil Riskesdas 2007 yang sebesar $2,13 \%$, period prevalence pneumonia berdasarkan diagnosis/gejala pada tahun 2013 mengalami penurunan menjadi $1,8 \%$.Pada balita, period prevalence berdasarkan diagnosis sebesar 2,4 per 1.000 balita dan berdasarkan diagnosis/gejala sebesar 18,5 per 1.000 balita $^{9,10}$

\section{METODE PENELITIAN}

Penelitian ini menggunakan data sekunder yaitu data dari laporan kasus di wilayah kerja Dinas Kesehatan Kabupaten Gowa Sulawesi Selatan tahun 2017. Laporan kasus survei dengan desain potong lintang (cross sectional study), untuk mendapatkan gambaran kasus pneumonia di wilayah kerja Dinas Kesehatan Kabupaten Gowa. Populasi sampel dalam laporan kasus 2017 adalah seluruh rumah tangga di wilayah kerja Dinas Kesehatan Kabupaten Gowa. Pendekatan kuantitatif dilakukan melalui analisis data sekunder kasus pneumonia tahun 2017, selanjutnya dilakukan literature review

Teknik pengambilan sampel berdasarkan diagnose tenaga kesehatan yang ada di puskesmas yang selanjutnya dikirim ke Dinas Kesehatan kabupaten Gowa per bulan. Kriteria inklusi yaitu pengunjung puskesmas yang memenuhi kreteria umur dan diduga menderita pneumonia oleh tenaga kesehatan. Serta mereka yang dalam proses perawatan di fasilitas kesehtan. Kriteria eksklusi sampel yaitu pasien yang datang ke puskesmas tetapi dengan menderita infeksi lainnya. Pasien yang memenuhi kriteria inklusi selanjutnya dikumpulkan data anamnesis, pemeriksaan fisik, pemeriksaan laboratorium.

Menegakkan diagnosis pneumonia pada pasien usia lanjut masih merupakan tantangan bagi para klinisi mengingat tampilan klinis yang tidak lengkap dan tidak spesifik. Gejala dan tanda pneumonia yang khas sering tidak 
didapatkan pada pasien usia lanjut. Metlay, dkk. ${ }^{10}$ dan Fernandez, dkk. ${ }^{11}$ yang melakukan studi pada pasien usia lanjut dengan pneumonia, melaporkan bahwa gejala-gejala saluran pernapasan seperti batuk dan sesak napas lebih jarang dikeluhkan pada kelompok usia yang lebih tua. Sementara itu, gejala berupa nyeri dada pleuritik dan hemoptisis lebih banyak pada kelompok usia muda. Hasil temuan fisik yang konsisten dengan diagnosis pneumonia komunitas sama sekali tidak ditemukan pada 20\%-47\% pasien usia lanjut. Sesak napas dan ronki pada umumnya lebih sering ditemukan. ${ }^{12}$

Proyeksi Jumlah Penduduk Menurut Kecamatan di Kabupaten Gowa

\begin{tabular}{|c|c|c|c|c|c|}
\hline \multirow[t]{2}{*}{ No. } & \multirow[t]{2}{*}{ Kecamatan } & \multirow{2}{*}{$\begin{array}{c}\text { Luas } \\
\text { Terbangun } \\
(\mathrm{Ha})\end{array}$} & \multicolumn{2}{|c|}{ Penduduk Tahun 2017} & \multirow[t]{2}{*}{ Keterangan } \\
\hline & & & $\begin{array}{c}\text { Jumlah } \\
\text { (Jiwa) }\end{array}$ & $\begin{array}{l}\text { Kepadatan } \\
\left(\mathrm{Jiwa} / \mathrm{Km}^{2}\right)\end{array}$ & \\
\hline 1. & Bontonompo & 596 & 41.317 & 1.360 & Perkotaan \\
\hline 2. & Bontonompo Selatan & 460 & 29.937 & 1.024 & Perkotaan \\
\hline 3. & Bajeng & 910 & 65.543 & 1.091 & Perkotaan \\
\hline 4. & Bajeng Barat & 352 & 24.098 & 1.266 & Perkotaan \\
\hline 5. & Pallangga & 1.372 & 103.804 & 2.152 & Perkotaan \\
\hline 6. & Barombong & 579 & 36.304 & 1.756 & Perkotaan \\
\hline 7. & Somba Opu & 1.869 & 136.995 & 4.877 & Perkotaan \\
\hline 8. & Bontomarannu & 364 & 32.859 & 625 & Perkotaan \\
\hline 9. & Pattallassang & 315 & 23.007 & 270 & Perkotaan \\
\hline 10. & Parangloe & 241 & 17.417 & 79 & Perkotaan \\
\hline 11. & Manuju & 229 & 14.818 & 161 & Perkotaan \\
\hline 12. & Tinggimoncong & 330 & 23.278 & 163 & Perkotaan \\
\hline 13. & Tombolopao & 402 & 28.259 & 113 & Perdesaan \\
\hline 14. & Parigi & 213 & 13.764 & 103 & Perdesaan \\
\hline 15. & Bungaya & 245 & 16.663 & 95 & Perdesaan \\
\hline 16. & Bontolempangan & 213 & 14.019 & 98 & Perdesaan \\
\hline 17. & Tompobulu & 477 & 30.463 & 229 & Perdesaan \\
\hline 18. & Biringbulu & 597 & 34.012 & 156 & Perdesaan \\
\hline \multicolumn{2}{|c|}{ Jumlah } & 9.764 & 686.556 & 15.618 & \\
\hline
\end{tabular}

Sumber : Buku Putih Sanitasi Bab 2

Pneumonia komunitas atau community acquired pneumonia (CAP) merupakan salah satu masalah kesehatan yang sering dijumpai dan mempunyai dampak yang signifikan di seluruh dunia, terutama pada populasi usia lanjut. Insiden pneumonia komunitas dilaporkan meningkat sesuai dengan bertambahnya usia.35 Pada pasien usia $\geq 65$ tahun yang dirawat di rumah sakit, pneumonia merupakan diagnosis terbanyak ketiga. Angka ini menjadi semakin penting mengingat bahwa diperkirakan sebanyak $20 \%$ dari penduduk dunia akan berusia lebih dari 65 tahun di tahun $2050 .{ }^{12}$

\section{HASIL PENELITIAN}

Dari data yang terkumpul dengan beberapa variabel yang ditampilkan dalam beberpa tabel berikut tabel distribusi frekuensinya :

Tabel. 1.1 Distribusi Penemuan Kasus Pneumonia Balita Berdasarkan Jenis Kelamin di wilayah Kabupaten Gowa Tahun 2017

\begin{tabular}{lcc}
\hline \multicolumn{1}{c}{ Jenis Kelamin } & $\mathbf{n}$ & $\%$ \\
\hline Laki-laki & 501 & 57,7 \\
Perempuan & 367 & 42,3 \\
\hline Total & 868 & 100,0
\end{tabular}


Berdasarkan tabel di atas dapat diketahui bahwa penemuan kasus pneumonia tertinggi pada balita di wilayah Kabupaten Gowa adalah sebesar $57,7 \%$ pada balita laki-laki. Sedangkan sebesar $42,3 \%$ ditemukan pada balita perempuan

Tabel 1.2 Distribusi Penemuan Kasus Pneumonia Balita Berdasarkan Kecamatan di wilayah Kabupaten Gowa Tahun 2017

\begin{tabular}{llll}
\hline \multicolumn{1}{c}{ Kecamatan } & \multicolumn{1}{c}{$\mathbf{n}$} & & $\%$ \\
\hline Sombaopu & 239 & 27,5 & \\
Pallangga & 93 & 10,7 \\
Barombong & 81 & 9,3 \\
Bajeng & 213 & 24,5 \\
Bajeng Barat & 5 & 0,6 \\
Bontonompo Selatan & 1 & 0,1 \\
Bontonompo & 34 & 3,9 \\
Bontomarannu & 47 & 5,4 \\
Pattallassang & 106 & 12,2 \\
Parangloe & 3 & 0,4 \\
Manuju & 0 & 0,0 \\
Tinggimoncong & 16 & 1,8 \\
Parigi & 0 & 0,0 \\
Tombolopao & 24 & 2,8 \\
Tompobulu & 0 & 0,0 \\
Biringbulu & 0 & 0,0 \\
Bungaya & 3 & 0,4 \\
Bontolempangan & 3 & 0,4 \\
\hline Total & 868 & 100 \\
\hline
\end{tabular}

Berdasarkan tabel di atas dapat diketahui bahwa penemuan kasus pneumonia tertinggi pada balita di wilayah Kabupaten Gowa adalah sebesar $27,5 \%$ yang terdapat di
Kecamatan Sombaopu. Sedangkan penemuan kasus terendah pada balita di wilayah Kabupaten Gowa adalah sebesar $0,1 \%$ yang terdapat di Kecamatan Bontonompo Selatan

Tabel 1.3 Distribusi Penemuan Kasus Pneumonia Balita Berdasarkan Puskesmas di wilayah Kabupaten Gowa Tahun 2017

\begin{tabular}{llll}
\hline \multicolumn{1}{c}{ Puskesmas } & $\mathbf{n}$ & \% \\
\hline Sombaopu & 239 & 28,3 & \\
Samata & 0 & 0 & \\
Pallangga & 8 & 1,1 & \\
Kampili & 5 & 0,6 & \\
Mancobalang & 15 & 2,1 & \\
Kanjilo & 66 & 24,1 & \\
Bajeng & 205 & 1,1 & \\
Pa'bentengan & 8 & 0,6 & \\
Gentungan & 5 & 0,1 & \\
Bontonompo I & 1 & 4,2 & \\
Bontonompo II & 34 & 7,4 & \\
Bontomarannu & 47 & 12,1 \\
Pattallassang & 97 & 0,3 & \\
Paccelekang & 9 & 0 & \\
Parangloe & 3 & 2,4 \\
Manuju & 0 & 0 \\
Tinggimoncong & 16 & 4,6 \\
Parigi & 0 & 0
\end{tabular}




\begin{tabular}{lll} 
Tonrorita & 0 & 0 \\
Lauwa & 0 & 0 \\
Bontomalonro & 0 & 0 \\
Sapaya & 3 & 0,3 \\
Bt.Lempangan & 0 & 0 \\
Bontolempangan II & 3 & 0,3 \\
\hline Total & 868 & 100,0 \\
\hline
\end{tabular}

Berdasarkan tabel di atas dapat diketahui bahwa penemuan kasus pneumonia tertinggi pada balita di wilayah Kabupaten Gowa adalah sebesar $28,3 \%$ yang terdapat di Puskesmas Sombaopu. Sedangkan penemuan kasus terendah pada balita di wilayah Kabupaten Gowa adalah sebesar $0,1 \%$ yang terdapat di Puskesmas Bontonompo I

\section{PEMBAHASAN}

Apabila dibandingkan dengan angka nasional Riskesdas tahun 2013 dengan angka Riskesdas 2018 di Kabupaten Gowa terljadi penurunan. Yaitu dari 2,5\% turun ke 1,5\%. Angka 1,5\% di 2018 juga masih dibawah angka nasional 2018 yaitu 2\%. Ini terbukti dari analisis tabel penelitian diatas. Artinya secara nasional kasus pneumonia naik. Tetapi di Kabupaten Gowa justru terjadi penurunan nilai prevalensinya.

Dari hasil penelitian diatas menunjukkan bahwa di wilayah kerja Dinas Kesehatan Kabupaten Gowa kasus pneumonia dari tahun 2013 dan pada tahun 2018 menurun. Dari tabel ditemukan bahwa sebesar $28,3 \%$ yang terdapat di Puskesmas Sombaopu. Sedangkan penemuan kasus terendah pada balita di wilayah Kabupaten Gowa adalah sebesar 0,1\% yang terdapat di Puskesmas Bontonompo I ini artinya terjadi kemungkinan karena jumlah penduduk di daerah tersebut lebih banyak. Salah satu factor dalam peningkatan kasus pneumonia adalah jumlah penduduk. Sesuai dengan penelitian dari Athena Anwar dan Ika Dharmayanti serta penelitian serupa oleh Yulia Efni1, Rizanda Machmud, Dian Pertiwi

\section{KESIMPULAN DAN SARAN}

Ditemukan bahwa penyakit pneumonia masih ditemukan di wilayah kerja dinas Kesehatan Kabupaten Gowa Propinsi Sulawesi Selatan. Daerah yang masih banyak dijumpai kasus pneumonia adalah di wilayah kerja puskesmas Sombaopu. Daerah ini ternyata uga daerah yang paling banyak penduduknya.
Tentunya perlunya diperhatikan perilaku hidup sehat terhadap mereka secara keseluruhan mulai dari lingkungan rumah dan luar rumah dan juga untuk menjaga konsumsi pola makan dan kandungan gizinya. Perlunya program wajib pemberian suplemen pada bumil dan bayi sehingga diharapankan akan terjadi kekebalan pada anak tersebut.

\section{UCAPAN TERIMAKASIH}

Terimakasih penulis sampaikan kepada Kepala Badan Penelitian dan Pengembangan Kesehatan dan Kepala Puslitbang Sumber Daya dan Pelayanan Kesehatan Badan Litbangkes Kementerian Kesehatan yang telah memberikan kesempatan untuk melakukan penulisan di Journal Poltekes Makasar, dan kepada semua pihak yang telah membantu sehingga penulisan artikel ilmiah ini bisa dipublikasikan. Terimakasih kepada Ibu Dyah Dinkes Kab Gowa dan tim Redaksi Journal Poltekes Makasar yang telah membantu sehingga artikel ini bisa dipublikasikan.

\section{DAFTAR PUSTAKA}

Kementerian Kesehatan Republik Indonesia. Pedoman pengendalian infeksi saluran pernafasan akut. Jakarta: Direktorat Jenderal Pengendalian Penyakit dan Pengendalian Lingkungan, Kementerian Kesehatan Republik Indonesia; 2012.

World Health Organization. Pneumonia. Fact sheet $N^{\circ} 331$ [cited 2013 Nov 13]. Available from: http://www.who.int/mediacentre/factsheet s/fs331/en/2013

http://www.depkes.go.id/resources/download/ge neral/Hasil\%20Riskesdas\%202013.pdf

.http://www.depkes.go.id/resources/download/p usdatin/profil-kesehatanindonesia/Indonesia\%20Health\%20Profil e\%202013\%20\%20v2\%20untuk\%20web.pdf 
Badan Pusat Statistik, Badan Kependudukan dan Keluarga Berencana Nasional, Departemen Kesehatan. Survei demografi dan kesehatan Indonesia 2007. Jakarta: Badan Pusat Statistik, Badan Kependudukan dan Keluarga Berencana Nasional, Departemen Kesehatan; 2013

Rudan I, Cynthia BP, Zrinka B, Kim M, Harrys C. Epidemiology and etiology of childhood pneumonia. Bulletin of the World Health Organization. 2008:408-16

Departemen Kesehatan RI. Riset kesehatan dasar (Riskesdas). Jakarta. Badan Penelitian dan Pengembangan Kesehatan Departemen Kesehatan RI. 2010 (diunduh 3 Januari 2014). Tersedia dari: URL: http://www.litbang.depkes.go.id/sites/ download/buku_laporan/lapnas_riskesda s2010/Laporan_riskesdas_2010. Pdf

Faktor Risiko yang Berhubungan dengan Kejadian Pneumonia pada Balita di Kelurahan Air Tawar Barat Padang. Jurnal Kesehatan Andalas. 2016; 5
Niederman MS, Ahmed QA. Communityacquired pneumonia in elderly patients. Clin Geriatr Med. 2003;19(1):101-20.

Pneumonia pada Anak Balita di Indonesia, Athena Anwar, Ika Dharmayanti Pusat Teknologi Intervensi Kesehatan Masyarakat Badan Penelitian dan Pengembangan Kesehatan Kementerian Kesehatan RI, Kesmas, Jurnal Kesehatan Masyarakat Nasional Vol. 8, No. 8, Mei 2014

Faktor Risiko Pneumonia pada Balita di Indonesia: Narative Review Penelitian Akademik Bidang Kesehatan Masyarakat Jurnal Kesehatan Masyarakat, Vol. 10, No. 2, September 2016, pp. $57 \sim 62$

Faktor-Faktor yang Berhubungan dengan Diagnosis Pneumonia pada Pasien Usia Lanjut Elza Febria Sari1,2, C. Martin Rumende3, Kuntjoro Harimurti4 Jurnal Penyakit Dalam Indonesia | Vol. 3, No. 4 | Desember 2016 